Jeremy M. Roschelle, Ph.D., is a senior cognitive scientist at the Center for Technology in Learning at SRI International, an inde pendent research organization in $M$ enlo Park, CA.

Roy D. Pea, D.Phil., $O x n_{\text {., }}$ is director of the Center for Technology in Learning at SRI International, an inde pendent research organization in M enlo Park, $\mathrm{CA}$; and consulting professor at the School of Education at Stanford University.

Christopher M . H oadley, Ph.D., is a research and computer scientist at the Center for Technology in Learning at SRI International, an inde pendent research organization in $\mathrm{M}$ enlo Park, CA.

Douglas N. Gordin, Ph.D., is a research staff member at IBM 's T.J. Watson Research Center, Applied Learning Services Department in Yorktown, NY.

Barbara M. Means, Ph.D., is codirector of the Center for Technology in Learning at SRI International, an independent research organization in $\mathrm{Menlo}$ Park, CA.

\section{Changing How and What Children Learn in School with Computer-Based Technologies}

\author{
J eremy M. Rosc helle, Roy D. Pea, Christopher M. Hoa dley, \\ Douglas N. Gordin, Barbara M. Means
}

\begin{abstract}
Schools today face ever-increasing demands in their attempts to ensure that students are well equipped to enter the workforce and navigate a complex world. Research indicates that computer technology can help support learning, and that it is especially useful in developing the higher-order skills of critical thinking, analysis, and scientific inquiry. But the mere presence of computers in the classroom does not ensure their effective use. Some computer applications have been shown to be more successful than others, and many factors influence how well even the most promising applications are implemented.

This article explores the various ways computer technology can be used to improve how and what children learn in the classroom. Several examples of computer-based applications are highlighted to illustrate ways technology can enhance how children learn by supporting four fundamental characteristics of learning: (1) active engagement, (2) participation in groups, (3) frequent interaction and feedback, and (4) connections to real-world contexts. Additional examples illustrate ways technology can expand what children learn by helping them to understand core concepts in subjects like math, science, and literacy. Research indicates, however, that the use of technology as an effective learning tool is more likely to take place when embedded in a broader education reform movement that includes improvements in teacher training, curriculum, student assessment, and a school's capacity for change. To help inform decisions about the future role of computers in the classroom, the authors conclude that further research is needed to identify the uses that most effectively support learning and the conditions required for successful implementation.
\end{abstract}

teacher from the late nineteenth century entering a typical classroom today would find most things quite familiar: chalk and talk, as well as desks and texts, predominate now as they did then. Yet this nineteenth-century teacher would be shocked by the demands of today's curricula. For example, just a century ago, little more was expected of high 
school students than to recite famous texts, recount simple scientific facts, and solve basic arithmetic problems. Only 3.5\% of students were expected to learn algebra before completing high school. ${ }^{1}$ Today, all high school students are expected to be able to read and understand unfamiliar text ${ }^{2}$ and to become competent in the processes of scientific inquiry and mathematics problem solving, including algebra. ${ }^{3}$ This trend of rising expectations is accelerating because of the explosion of knowledge now available to the public and the growing demands of the workplace. ${ }^{4}$ More and more students will have to learn to navigate through large amounts of information and to master calculus and other complicated subjects to participate fully in an increasingly technological society. ${ }^{5}$ Thus, although the classroom tools of blackboards and books that shape how learning takes place have changed little over the past century, societal demands on what students learn have increased dramatically.

There is consensus among education policy analysts that satisfying these demands will require rethinking how educators support learning. ${ }^{6}$ Debate now focuses on identifying and implementing the most appropriate and highest priority reforms in the areas of curricula, teacher training, student assessment, administration, buildings, and safety. The role that technology could or should play within this reform movement has yet to be defined. Innovations in media technology, including radio, television, film, and video, have had only isolated, marginal effects on how and what children learn in school, despite early champions of their revolutionary educational potential. 7 (See the article by Wartella and Jennings in this journal issue.) Similarly, although computer technology is a pervasive and powerful force in society today with many proponents of its educational benefits, it is also expensive and potentially disruptive or misguided in some of its uses and in the end may have only marginal effects. Nevertheless, several billion dollars in public and private funds have been dedicated to equipping schools with computers and connections to the Internet, and there are promises of even more funds dedicated to this purpose in the future. ${ }^{8}$ (See Appendix A in this journal issue for more information on sources of funding.) As everincreasing resources are committed to bringing computers into the classroom, parents, policymakers, and educators need to be able to determine how technology can be used most effectively to improve student learning. ${ }^{9}$

This article explores the characteristics of computer technology and its potential to enhance learning. The first section highlights a number of computer-based technology applications shown to be effective in improving how and what children learn. Of course, just because computer technology can lead to improvements in learning does not mean that it will do so simply 
because technology is infused into the classroom. Studies overwhelmingly suggest that computer-based technology is only one element in what must be a coordinated approach to improving curriculum, pedagogy, assessment, teacher development, and other aspects of school structure. Therefore, the second section of this article discusses the changes in organizational structures and supports that should be considered when schools are planning a strategy for incorporating technology. This article concludes with a brief discussion of a framework to guide future research efforts.

\section{Efiective Use of Technology as a leaming Tol}

Studies conducted on the effectiveness of technology in the classroom often have mixed results, making it difficult to generalize about technology's overall impact in improving learning.10,11 For example, in one of the few large-scale studies conducted nationwide, some approaches to using educational technology were found to increase fourth- and eighth-grade students' mathematical understanding, whereas others proved less effective. 12 M ore specifically, computer-based applications that encouraged students to reason deeply about mathematics increased learning, whereas applications that attempted to make repetitive skill practice more entertaining for students actually seemed to decrease performance. In contrast, a meta-analysis of more than 500 research studies of computer-based instruction found positive effects on student achievement tests resulted primarily from computer tutoring applications; other uses of the computer, such as simulations and enrichment applications, were found to have only minimal effects. ${ }^{13}$ (See Table 1 at the end of this article for a summary of findings from these and several other major studies on the effects of technology use in kindergarten through 12th-grade classrooms.)

Three key reasons contribute to these mixed results. First, hardware and software vary among schools, and there is even greater variation in the ways schools use technology, so the failure to produce uniform results is not surprising. Second, successful use of technology is always accompanied by concurrent reforms in other areas such as curriculum, assessment, and teacher professional development, so the gains in learning cannot be attributed to use of technology alone. And third, rigorously structured longitudinal studies that document the isolated effects of technology are expensive and difficult to implement, so few have been conducted.

Although today's research can support only limited conclusions about the overall effectiveness of technology expenditures in improving education, studies conducted to date suggest that certain computer-based applications can enhance learning for students at various achievement levels. The following sections highlight several promising applications for improving how and what children learn. The "how" and the "what" are separated because not only can technology help children learn things better, it also can help them learn better things. Framed in terms of the growing expectations in mathematics instruction, the "how" addresses the problem of enhancing the learning of the $70 \%$ to $100 \%$ of students already expected to learn algebra. The "what" addresses the problem of making it possible for the vast majority of students to go beyond algebra to learn calculus - a topic that is unreachable for most students without a revitalized curriculum that takes advantage of technology.

Based on the research to date, the strongest evidence showing positive gains in learning tends to focus on applications in science and mathematics for upper elementary, middle, and high school students. This evidence generally applies to both boys and girls. Future research may find gains that are equally strong for the lower elementary grades and across other curriculum areas or that are gender or age specific. The discussion below reflects the limitations of the research to date, however, and although promising applications across a variety of subjects are considered, applications in the areas of science and mathematics are most often highlighted.

\section{Enhanc ing How Children Leam} A major scientific accomplishment of the 
twentieth century has been the great advancements in understanding cognition-that is, the mental processes of thinking, perceiving, and remembering. ${ }^{14}$ For example, cognitive research has shown that learning is most effective when four fundamental characteristics are present: ( 1 ) active engagement, (2) participation in groups, (3) frequent interaction and feedback, and (4) connections to realworld contexts. Interestingly, some of the pioneers in learning research also have been pioneers in exploring how technologies can improve learning. These connections are not coincidental. As scientists have understood more about the fundamental characteristics of learning, they have realized that the structure and resources of traditional classrooms often provide quite poor support for learning, whereas technology-when used effectively - can enable ways of teaching that are much better matched to how children learn. The following discussion describes specific computer-based technologies that have been shown to support each of the four fundamental characteristics of learning.

Leaming Through Active Engagement Learning research has shown that students learn best by actively "constructing" knowledge from a combination of experience, interpretation, and structured interactions with peers and teachers. ${ }^{14,15}$ When students are placed in the relatively passive role of receiving information from lectures and texts ( the "transmission" model of learning), they often fail to develop sufficient understanding to apply what they have learned to situations outside their texts and classrooms. ${ }^{16}$ In addition, children have different learning styles. The use of methods beyond lectures and books can help reach children who learn best from a combination of teaching approaches. ${ }^{17}$ Today's theories of learning differ in some details, ${ }^{18}$ but educational reformers appear to agree with the theoreticians and experts that to enhance learning, more attention should be given to actively engaging children in the learning process. Curricular frameworks now expect students to take active roles in solving problems, communicating effectively, analyzing information, and designing solutions - skills that go far beyond the mere recitation of correct responses. 19
Although active, constructive learning can be integrated in classrooms with or without computers, the characteristics of computer-based technologies make them a particularly useful tool for this type of learning. For example, consider science laboratory experiments. Students certainly can actively engage in experiments without computers, yet nearly two decades of research has shown that studentscan make significant gains when computers are incorporated into labs under a design called the "M icrocomputer-Based Laboratory" (MBL). As illustrated by the description of an MBL in Box 1, students conducting experiments can use computers to instantaneously graph their data, thus reducing the time between gathering data and beginning to interpret it.

\section{The structure and resources of traditional classrooms often provide quite poor support for learning, whereas technology- when used effectively- can enable ways of teaching that are much better matched to how children learn.}

Students no longer have to go home to laboriously plot points on a graph and then bring the graphs back to school the following day. Instead, they instantaneously can see the results of their experiment. In fairly widely replicated studies, researchers have noted significant improvements in students' graph-interpretation skills, understanding of scientific concepts, and motivation when using the software. ${ }^{20}$ For example, one study of 125 seventh and eighth graders found that use of MBL software resulted in an $81 \%$ gain in the students' ability to interpret and use graphs.21 In another study of 249 eighth graders, experience with MBL was found to produce significant gains in the students' ability to identify some of the reasons why graphs may be inaccurate. 22

Using technology to engage students more actively in learning is not limited to science and mathematics. For example, computer-based applications such as desktop publishing and desktop video can be used to involve students more actively in constructing presentations that reflect their understanding and knowledge of various 


\section{Box 1}

\section{A Mic rocomputer-Based Laboratory in Creek Biology}

Two sixth-grade science classes grab their palmtop computers with chemical sensors attached, and head out for a field trip to the local creek. For more than five years, teachers at this school have taken their sixth-grade science classes on this field trip. But before the advent of palmtop computers, their students collected water samples and jotted down observations during the field trip, then returned to the classroom to analyze the $\mathrm{pH}$, oxygenation, and other measures of the health of the creek. These tests took days of dripping indicator solutions into test tubes of creek water and laborious charting of the outcomes.

Today, with the help of the palmtop computers, students can measure the creek and see the results of their data gathering while still in the field. The computers store and graph the data immediately, allowing students to see how the graphs unfold in real time, directly related to their observations. The immediacy of the process helps students understand what the graph's time axis means, a challenge for many students who have only recently learned how to plot points. In addition, students are able to develop their critical thinking skills by analyzing their initial results and running follow-up experiments the same day.

Source: For more information, see Web site at http://probesight.concord.org or http://www.concord.org/ -shemy/cilt/.

subjects. Although previous media technologies generally placed children in the role of passive observers, these new technologies make content construction much more accessible to students, and research indicates that such uses of technology can have significant positive effects. In one project, innercity high school students worked as "multimedia designers" to create an electronic school yearbook and displays for a local children's museum. The students participating in the project showed significant gainsin task engagement and self-confidence measures compared with students enrolled in a more traditional computer class. ${ }^{23}$

\section{Leaming Through Participation \\ in Groups}

One influential line of learning research focuses on the social basis for children's learning, inspired by the seminal research of the Russian psychologist Vygotsky. ${ }^{24}$ Social contexts give students the opportunity to successfully carry out more complex skills than theycould execute alone. Performing a task with others provides an opportunity not only to imitate what others are doing, but also to discuss the task and make thinking visible. Much learning is about the meaning and correct use of ideas, symbols, and representations. Through informal social conversation and gestures, students and teachers can provide explicit advice, resolve misunderstandings, and ensure mistakes are corrected. In addition, social needs often drive a child's reason for learning. Because a child's social identity is enhanced by participating in a community or by becoming a member of a group, 25 involving students in a social intellectual activity can be a powerful motivator and can lead to better learning than relying on individual desk work.

Some critics feel that computer technology encourages asocial and addictive behavior and taps very little of the social basis of learning. Several computer-based applications, such as tutorials and drill-and-practice exercises, do engage students individually. H owever, projects that use computers to facilitate educational collaboration span nearly the entire history of the Internet, dating back to the creation of electronic bulletin boards in the 1970s. ${ }^{26}$ Some of the most prominent uses of computers today are communications oriented, and networking technologies such as the Internet and digital video permit a broad new range of collaborative activities in schools. Using technology to promote such collaborative activities can enhance the degree to which classrooms are socially active and productive and can encourage classroom conversations that expand students' understanding of the subject. ${ }^{27}$ 
One major, long-term effort that exemplifies many of the promising features of collaborative technology is the ComputerSupported Intentional Learning Environment (CSILE, pronounced "Cecil").28 The goal of CSILE is to support structured collaborative knowledge building by having students communicate their ideas and criticisms - in the form of questions, statements, and diagrams - to a shared database classified by different types of thinking (see Box 2 2). By classifying the discussion in this way, students become more aware of how to organize their growing knowledge. In addition, CSILE permits students or experts to participate independent of their physical location. Students can work with other students from their classroom or school or from around the globe to build a common understanding of some topic. As illustrated in Figure 1, students in K-12 classes who use CSILE for science, history, and social studies perform better on standardized tests and create deeper explanations than students in classes without this technology. ${ }^{29}$ Although all students show improvement, positive effects are especially strong for students categorized as low or middle achievers. ${ }^{30}$

Many types of learning networks have been created for use in classrooms at all levels. For example, the AT\&T Learning Circles project uses computer networking for multicultural and multilingual collaborative learning by partnering classrooms in different countries to produce newsletters or other writing projects.31 The Multimedia Forum Kiosk and SpeakEasy projects ${ }^{32}$ structure students' collaborative interactions, resulting in more inclusive and genderequitable participation than ordinarily occursin face-to-face classroom discussions. ${ }^{33}$ Convince $\mathrm{Me}$ and Belvedere systems help students to distinguish between hypotheses and evidence and to produce clearer scientific explanations. ${ }^{34}$ Reportsfrom researchers and teachers suggest that students who participate in computer-connected learning networks show increased motivation, a deeper understanding of concepts, and an increased willingness to tackle difficult questions. 31,35

\section{Leaming Through Frequent Interaction and Feedlback \\ In traditional classrooms, students typically have very little time to interact with materi- als, each other, or the teacher. ${ }^{36}$ Moreover,

students often must wait days or weeks after handing in classroom work before receiving feedback. In contrast, research suggests that learning proceeds most rapidly when learners have frequent opportunities to apply the ideas they are learning and when feedback on the success or failure of an idea comes almost immediately. 37

Unlike other media, computer technology supports this learning principle in at least three ways. First, computer tools themselves can encourage rapid interaction and feedback. For example, using interactive graphing, a student may explore the behavior of a mathematical model very rapidly, getting a quicker feel for the range of variation in the model. If the same student

\section{Students who participate in computer- connected learning networks show increased motivation, a deeper understanding of concepts, and an increased willingness to tackle difficult questions.}

graphed each parameter setting for the model by hand, it would take much longer to explore the range of variation. Second, computer tools can engage students for extended periods on their own or in small groups; this can create more time for the teacher to give individual feedback to particular children. 38 Third, in some situations, computer tools can be used to analyze each child's performance and provide more timely and targeted feedback than the student typically receives 39

Research indicates that computer applications such as those described above can be effective tools to support learning. 40 One study compared two methods of e-mailbased coaching. In the first method, tutors generated a custom response for each student. In the second, tutors sent the student an appropriate boilerplate response. ${ }^{41}$ Students' learning improved significantly and approximately equally using both methods, but the boilerplate-based coaching allowed four times as many students to have access to a tutor. 42 In another version of computer-assisted feedback, a program called Diagnoser assesses students' understanding of physics concepts in situations 


\section{Box 2}

\section{The Computer-Supported Intentional Leaming Environment (CSILE) Project}

Two elementary school classes, one in northern Canada and one in rural Scandinavia, have set arctic elk as the topic for their CSILE project for the next few weeks. The CSILE software was designed based on a radical notion: that young students can and should be treated as junior scholars. CSI LE is a community database that students use to share their findings as they do research alone, in small groups, as a whole class, or-as in this case-across classrooms. The students work enthusiastically with their teachers to come up with researchable questions based on both library research and real-world observations or experiments. As the students pursue the questions they find most interesting, they put their ideas, questions, and findings into the CSILE software system as notes and share them with their peers across the ocean. The notes are classified into types of thinking such as "My theory for now..." or "What I need to know next is...." Through the prompting of these different categories, their teachers' guidance, and the critique and questions of their distant peers, students support and refine their ideas online. The students express their ideas both in text and graphics, and in this case students use a mix of languages: English, Inuit, and Finnish. Not only does their understanding of elk improve, but they also gain valuable writing and language skills and a better multicultural understanding.

Source: For more information, see Web site at http://c sile.oise.utoronto.ca/.

where students typically make mistakes, then provides teachers with suggested remedial activities (see Box 3). 43 Data from experimental and control classrooms showed scores rising more than $15 \%$ when teachers incorporated use of Diagnoser, and the results were equally strong for low, middle, and high achievers.

The most sophisticated applications of computers in thisarea have tried to trace students' reasoning process step by step, and provide tutoring whenever students stray from correct reasoning. Results from Geometry Tutor, an application that uses this approach, showed students-especially average or lower achievers or students with low self-confidence in mathematics - could learn geometry much faster with such help. ${ }^{44}$ Also, researchers at Carnegie M ellon University found that urban high school students using another application, Practical Algebra Tutor, showed small gains on standardized math tests such as the Scholastic Aptitude Test (SAT), but more than doubled their achievement in complex problem solving compared to students not using this technology. 45

\section{Leaming Through Connections to} Real-Wbild Contexts

One of the core themes of twentieth-century learning research has been students' frequent failure to apply what they learn in school to problems they encounter in the real world. A vast literature on this topic suggests that, to develop the ability to transfer knowledge from the classroom to the real world, learners must master underlying concepts, not simply memorize facts and solution techniques in simplified or artificial contexts. ${ }^{14}$ But typical problem-solving assignments do not afford students the opportunity to learn when to apply particular ideas because it is usually obvious that the right ideas to apply are those from the immediately preceding text.

Computer technology can provide students with an excellent tool for applying concepts in a variety of contexts, thereby breaking the artificial isolation of school subject matter from real-world situations. For example, through the communication features of computer-based technology, students have access to the latest scientific data and expeditions, whether from a National 
Figure 1

\section{Gains Achieved by Sudents Participating in CSIF Projects}
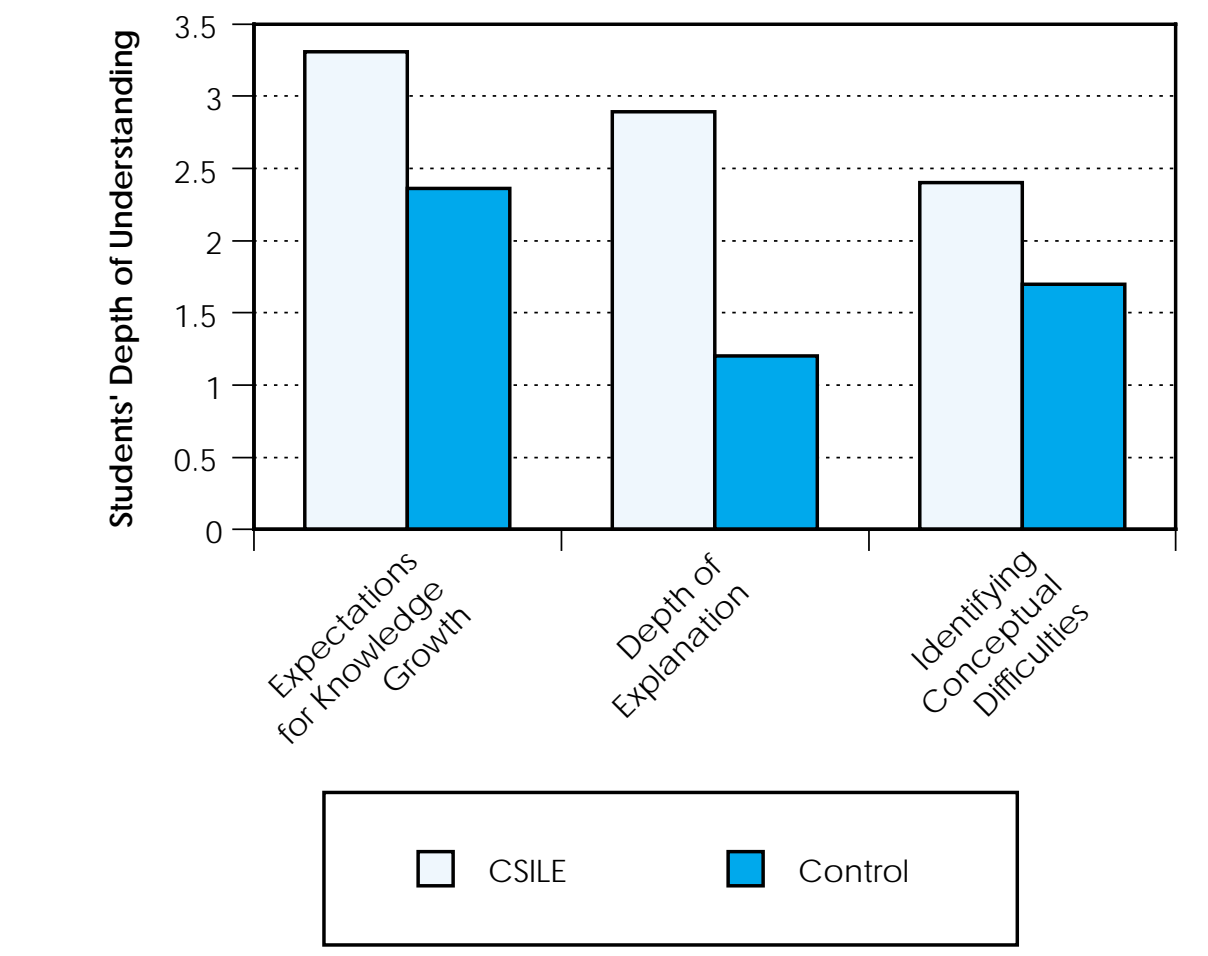

Source: Based on data reported in Scardamalia, M., Bereiter, C., Brett, C., et al. Educational applications of a networked communal database. Interactive Leaming Environments (1992) 2:45-71.

Air and Space Administration's (NASA) mission to Mars, an ongoing archeological dig in Mexico, or a remotely controlled telescope in Hawaii. Further, technology can bring unprecedented opportunities for students to actively participate in the kind of experimentation, design, and reflection that professionals routinely do, with access to the same tools professionalsuse. Through the Internet, students from around the world can work as partners to scientists, businesspeople, and policymakers who are making valuable contributions to society.

One important project that allows students to actively participate in a real-world research project is the Global Learning and Observations to Benefit the Environment (GLOBE) Program. Begun in 1992 by Vice President Al Gore as an innovative way to aid the environment and help students learn science, the GLOBE Program currentlylinks more than 3,800 schools around the world to scientists. 46 Teachers and students collect local environmental data for use by scientists, and the scientists provide mentoring to the teachers and students about how to apply scientific concepts in analyzing real environmental problems (see Box 4). Thus, the GLOBE Program depends on students to help monitor the environment while educating them about it. Further, the students are motivated to become more engaged in learning because they are aiding real scientific research-and their data collection has lasting value. In a 1998 survey, $62 \%$ of teachers using the GLOBE Program reported that they had students analyze, discuss, or interpret the data. Although no rigorous evaluations of effects on learning have been conducted, surveyed GLOBE teachers said they view the program as very effective and indicated that the greatest student gains occurred in the areas of observational and measurement skills, ability to work in small groups, and technology skills. ${ }^{47}$

Similarly, in the Global Lab Curriculum project, scientists have crafted techniques 


\section{Box 3}

\section{Diagnoser}

Students studying buoyancy in their science class log on to their computers and are walked through a series of questions using Diagnoser while they observe a demonstration of buoyancy. Demonstrations like this one are common in science courses. What is unusual here is that, with the help of Diagnoser, the teacher is asking the students to explain the demonstration rather than the other way around. The series of questions posed by Diagnoser helps the teacher understand exactly how the students are reasoning about the situation and develop a road map for future instruction. This technique, called benchmarking, allows teachers to build on the ideas students al ready have rather than expect them to abandon their instincts and experience on faith alone. Afterward, the teacher may work through a faulty prediction with students to help them refine their ideas. Without the support of the computer, such benchmarking would require teachers to spend considerable time with each student to uncover their particular preconceptions and would be too time-consuming for most classroom situations. By using the Diagnoser software, however, benchmarking is made more feasible because much of the process is automated.

Source: For more information, see Web site at http://depts.washington.edu/huntlab/diagnoser/ .

that allow students around the world to gather and share data about the terrestrial, aquatic, and aerial aspects of their locale.48 They study local soil quality, the electrical conductivity and $\mathrm{pH}$ of rain, and ultraviolet radiation, airborne particulates, and carbon dioxide in the air. Results are pooled through telecommunications, and students analyze their data with peers and scientists from around the world. Many other projects also connect teachers and students with scientists to allow active engagement in realworld experiences. For example, the Jason Project, originated by world-famous explorer Robert Ballard, invites students along on scientific expeditions with "telepresence" connections over the Internet. ${ }^{49}$ In these expeditions, students communicate with scientists who are exploring coral reefs or studying a rain forest. In the KidSat project, students direct the operation of a camera on a NASA space shuttle.50

Projects also have been developed to connect students with real-world experiences in nonscience subject areas. For example, the Jasper Project demonstrated significant improvements in mathematical understanding when teachers used videodiscs of adventure stories that encouraged students to engage in meaningful mathematical problem solving.51 Researchers assessed the Jasper Project's effectiveness in 28 middle schools in 9 states. After a month, students using the technology scored about the same on standardized math tests, but showed significant improvement in their ability to solve complex problems, and more positive attitudes toward the role of mathematics in solving real problems, compared with students not using the program. ${ }^{14}$

\section{Expanding What Children Leam}

In addition to supporting how children learn, computer-based technology can also improve what children learn by providing exposure to ideas and experiences that would be inaccessible for most children any other way. For example, because synthesizers can make music, students can experiment with composing music even before they can play an instrument. Because communications technology makes it possible to see and talk to others in different parts of the world, students can learn about archeology by following the progress of a real dig in the jungles of M exico. Through online communications, students can reach beyond their own community to find teachers and other students who share their academic interests. 


\section{Box 4}

\section{The Global Leaming and Obsenvations to Benefit the Environment (GLOBE) Program}

Students participating in the GLOBE Program collect data on airborne particulate counts and cloud cover using everyday supplies, then enter their data into the computer as part of a worldwide scientific effort to monitor the environment through the Internet. As students prepare to upload their data, a lively debate on why the measurements differ leads to a discussion of sources of experimental error. The discussion carries over onto the Web, where a GLOBE scientist gives her input. After the class decides on their best measurement, the results are sent via Internet to the GLOBE Program where scientists await the data for use in their own research. The students are able to do their own scientific analysis by downloading results from identical experiments run by students worldwide and by using sophisticated visualization and modeling tools. Mean while, the students enjoy the satisfaction of knowing they have contributed to "grown-up" science.

Source: For more information, see Web site at http://www.globe.gov.

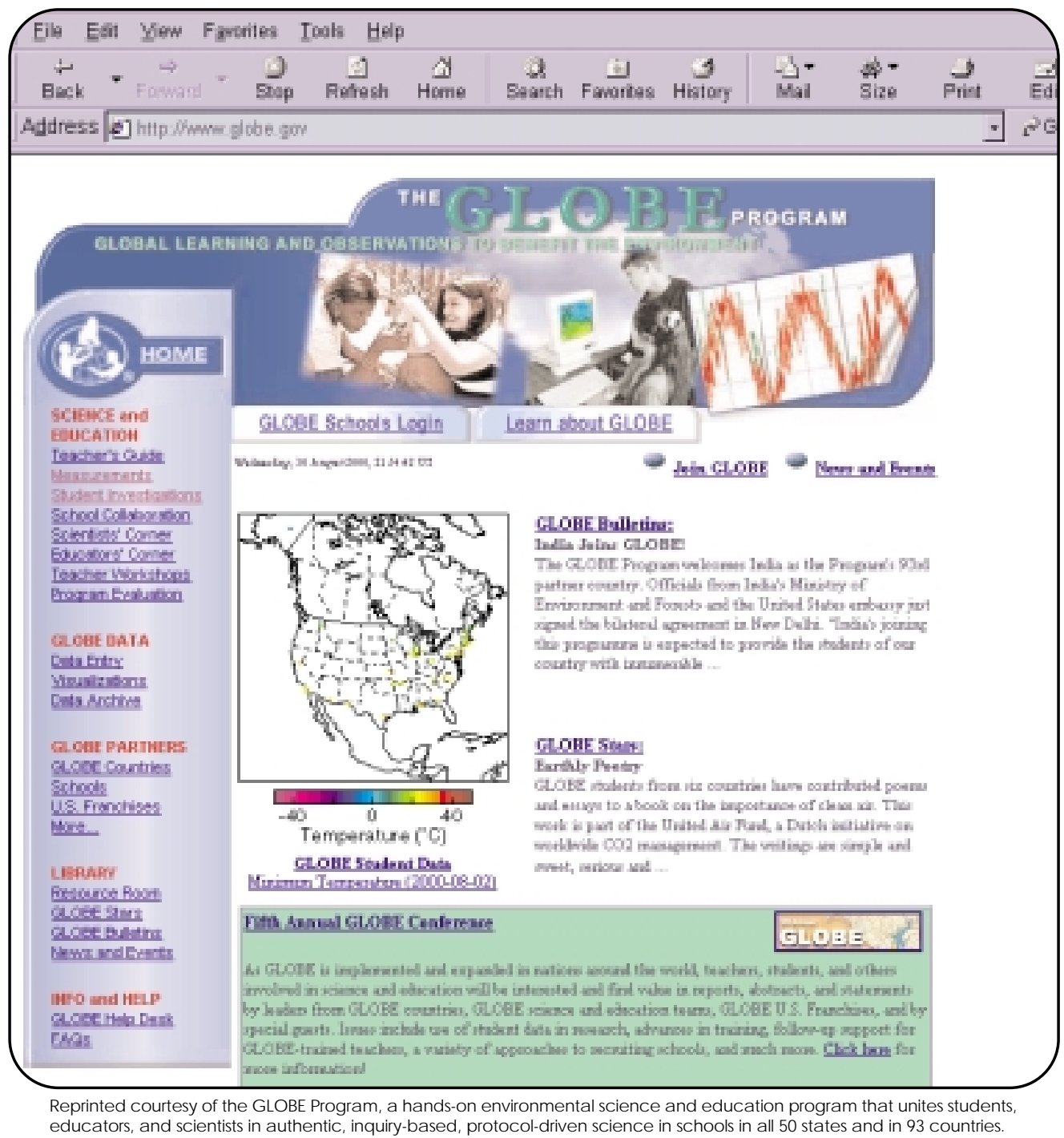




\section{PHOTO OMTIED}

The most interesting research on the ways technology can improve what children learn, however, focuses on applications that can help students understand core concepts in subjects like science, math, and literacy by representing subject matter in less complicated ways. Research has demonstrated that technology can lead to profound changes in what children learn. By using the computers' capacity for simulation, dynamically linked notations, and interactivity, ordinary students can achieve extraordinary command of sophisticated concepts. Computer-based applications that have had significant effects on what children learn in the areas of science, mathematics, and the humanities are discussed below.

\section{Science: Visualization, Modeling, and Simulation}

O ver the past two decades, researchers have begun to examine what students actually learn in science courses. To their surprise, even high-scoring students at prestigious universities show little ability to provide scientific explanations for simple phenomena, such as tossing a ball in the air. This widely replicated research shows that although students may be able to calculate correctly using scientific formulas, they often do not understand the concepts behind the formulas. 52
Computer-based applications using visualization, modeling, and simulation have been proven to be powerful tools for teaching scientific concepts. The research literature abounds with successful applications that have enabled students to master concepts usually considered too sophisticated for their grade level.53 For example, technology using dynamic diagrams - that is, pictures that can move in response to a range of input-can help students visualize and understand the forces underlying various phenomena. Involving students in making sense of computer simulations that model physical phenomena, but defy intuitive explanations, also has been shown to be a useful technique. One example of this work is ThinkerTools, a simulation program that allows middle school students to visualize the concepts of velocity and acceleration (see Box 5). ${ }^{54}$ In controlled studies, researchers found that middle school students who used ThinkerTools developed the ability to give correct scientific explanations of Newtonian principles several grade levels before the concept usually is taught. Middle school students who participated in ThinkerTools outperformed high school physics students in their ability to apply the basic principles of Newtonian mechanics to real-world situations: the middle schoolers averaged $68 \%$ correct answers on a six-item, multiple-choice test, 


\section{Box 5}

\section{Thinkertools}

Students using ThinkerTools view simulated objects on a screen, where they can adjust the settings to better understand the laws of physics. For example, it's pretty hard to believe that objects in motion stay in motion without the action of an external force, when our experiences, such as trying to drag a heavy object, tell us otherwise. It's even harder to visualize what that force might be and to understand the difference between, say, a force and a velocity. ThinkerTools, a software application developed in the 1980s, shows students what they cannot see in the real world. Simulated objects on the screen move according to the laws of physics ( with or without gravity and friction, depending on the settings). The big difference is that the computer can superimpose arrows representing force, acceleration, and/ or velocity, so that for the first time students can actually "see" the equation $\mathrm{F}=$ ma. Students can also change these arrows themselves to get a more intuitive sense of forces and motion.

Source: For more information, see Web site at http://thinkertools.berkeley.edu:7019/.

compared with $50 \%$ for the high school physics students. 55 Researchers concluded that the use of the ThinkerTools software appeared to make science interesting and accessible to a wider range of students than was possible with more traditional approaches.

Other software applications have been proven successful in helping students master advanced concepts underlying a variety of phenomena. The application Stella enables high school students to learn system dynamics - the modeling of economic, social, and physical situations using a set of interacting equations - which is ordinarily an advanced undergraduate course. ${ }^{56}$ Another software application uses special versions of Logo, a programming language designed especially for children, to help high school students learn the concepts that govern bird-flocking and highway traffic patterns, even though the mathematics needed to understand these concepts is not ordinarily taught until graduate-level studies.57 And yet another application, the Global Exchange curricula, reaches tens of thousands of precollege students annually with weather map visualizations that enable schoolchildren to reason like meteorologists. Research has shown that students using the curricula demonstrate increases in both their comprehension of meteorology and their skill in scientific inquiry. 58

\section{Mathematics: Dynamic, Linked Notations}

As suggested above, the central challenge of mathematics education is teaching sophisticated concepts to a much broader population than traditionally has been taught such material. This challenge is not unique to the United States-almost every nation is disappointed with the mathematical capabilities of their students. 59 Not so long ago, simple merchant mathematics (addition, subtraction, multiplication, and division) sufficed for almost everyone, but in today's society, people increasingly are called on to use mathematical skills to reason about uncertainty, change, trends in data, and spatial relations.

While seeking techniques for increasing how much mathematics students can learn, researchers have found that the move from traditional paper-based mathematical notations (such as algebraic symbols) to onscreen notations (including algebraic symbols, but also graphs, tables, and geometric figures) can have a dramatic effect. In comparison to the use of paper and pencil, which supports only static, isolated notations, use of computers allows for "dynamic, linked notations" with several helpful advantages, as described below: 60

- Students can explore changes rapidly in the notation by dragging with a mouse, as 
opposed to slowly and painstakingly rewriting the changes.

- Students can see the effects of changing one notation on another, such as modifying the value of a parameter of an equation and seeing how the resulting graph changes its shape.

- Students can easily relate mathematical symbols either to data from the real world or to simulations of familiar phenomena, giving the mathematics a greater sense of meaning.

- Students can receive feedback when they create a notation that is incorrect. (For example, unlike with paper and pencil, a computer can beep if a student tries to sketch a nonsensical mathematical function in a graph, such as one that "loops back" to define two different $y$ values for the same $x$ value.)

Using dynamic, linked notations, the SimCalc Project has shown that computers can help middle school students in some of the most challenging urban settings to learn calculus concepts such as rate, accumula-

\section{Computers can help middle school students in some of the most challenging urban settings to learn calculus concepts such as rate, accumulation, limit, and mean value.}

tion, limit, and mean value (see Box 6). 61 Studies across several different SimCalc field sites found that inner-city middle school students - many of whom ordinarily would be weeded out of mathematics before reaching this level-were able to surpass the efforts of college students in their understanding of fundamental concepts of calculus, based on a SimCalc assessment that stressed conceptual understanding of calculus, not symbolic computation. Results of the assessment showed that through exposure to SimCalc, inner-city middle school students increased their percentage of correct responses from only about $15 \%$ to $90 \%$ or more in a few months, whereas only $30 \%$ to $40 \%$ of collegelevel students answered some of these same items correctly. According to researchers, the capacity of computers to enable students to reason while directly editing dynamic graphs and related notations is the central innovation responsible for this breakthrough.

Another example of a software application using screen-based notations is Geometer's Sketchpad, a tool for exploring geometric constructions directly onscreen. Such applications are revitalizing the teaching of geometry to high school students, and in a few instances, students even have been able to contribute novel and elegant proofs to the professional mathematical literature.62 Graphing calculators, which are reaching millions of new high school and middle school students each year, are less sophisticated than some of the desktop computer-based technologies, but they can display algebra, graphs, and tables, and can show how each of these notations represents the same mathematical object. 63 Through the use of such tools, screen-based notations are enabling an expansion of mathematical literacy in a growing number of the nation's classrooms.

Social Studies, Language, and the Arts Unlike science and math, breakthrough uses of technology in other subject areas have yet to crystallize into easily identified types of applications. Nonetheless, innovators have shown that similar learning breakthroughs in these areas are possible. For example, the commercially successful Simcity game (which is more an interactive simulation than a traditional video game) has been used to teach studentsabout urban planning. Computer-based tools have been designed to allow students to choreograph a scene in a Shakespeare play ${ }^{64}$ or to explore classic movies, such as Citizen Kane, from multiple points of view to increase their ability to consider alternative literary interpretations.65 Through the Perseus Project, students are provided with access to a pioneering multimedia learning environment for exploring hyperlinked documents and cultural artifacts from ancient civilizations. ${ }^{66}$ Similar software can provide interactive media environments for classes in the arts. An emergent theme in many computerbased humanities applications is using technology that allows students to engage in an element of design, complementing and enhancing the traditional emphasis on appreciation. 


\section{Box 6}

\section{Simcalc}

A group of students is busily learning the basics of calculus. These aren't college freshmen, however, but rather middle school students working with the SimCalc software. Today the students are graphing rates of change. Using a SimCalc animation of a clown walking along a road and software that relates graphs of the motion to the animation itself, the students explore the difference between constant velocity and constant acceleration. I nitial ly, students are confused by how a velocity graph for the clown can be represented by a flat line. Soon, however, they begin to explore the differences between a graph of position and a graph of velocity in the online simulation.

Source: For more information, see Web site at http://www.simcalc.umassd.edu

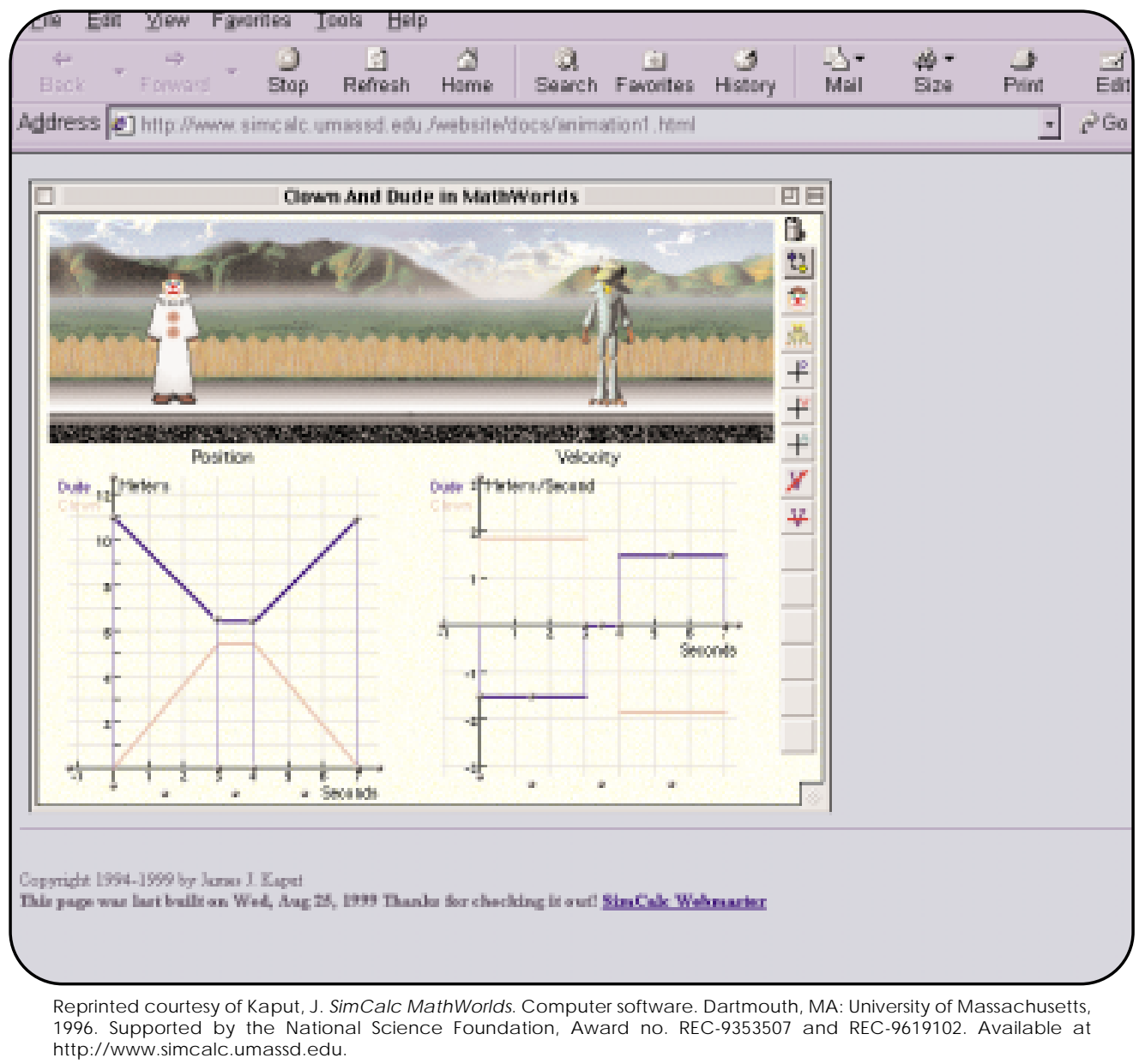

Although there are fewer studies on the effectiveness of technology use in these other subject areas, one recent study documented the experience of two sixth-grade classes participating in a social studies project on the Spanish colonization of Latin America. The study found that the students who used computers to create a multimedia

presentation on what they had learned scored significantly higher on a posttest, compared with members of the other sixthgrade class that completed a textbook-based unit on the same topic.67 Another study examined the effectiveness of using interactive storybooks to develop basic language skills and found that first graders using the 


\section{PHOTO OMTIED}

technology-based system demonstrated significantly greater gains compared with those receiving only traditional instruction. 68

In one innovative project, elementary and middle school children alternate between playing musical instruments, singing, and programming music on the computer using Tuneblocks, a musical version of the Logo programming language. 69 Compelling case studies show how using this software enables ordinary children to learn abstract musical concepts like phrase, figure, and meter-concepts normally taught in college music theory classes. In another example, a tool called Hypergami enables art students to plan complicated mathematical sculptures in paper.70 Experiences with $\mathrm{H}$ ypergami have produced significant gains in boys' and girls' performance on the spatial reasoning sections of the SAT.71

\section{The Challenges of Implementation}

The preceding overview provides only a glimpse of the many computer-based applications that can enhance learning. But simply installing computers and Internet access in schools will not be sufficient to replicate these examples for large numbers of learners. M odels of successful technology use combine the introduction of computer tools with new instructional approaches and new organizational structures. Because the American educational system is somewhat like an interlocking jigsaw puzzle, ${ }^{72}$ efforts to change one piece of the puzzle-such as using technology to support a different kind of content and instructional approach-are more likely to be successful if the surrounding pieces of teacher development, curriculum, assessment, and the school's capacity for reform are changed as well. Each of these organizational change factors is examined briefly below.

\section{Teac her Support}

Effective use of computers in the classroom requires increased opportunities for teachers to learn how to use the technology. Studies show that a teacher's ability to help students depends on a mastery of the structure of the knowledge in the domain to be taught. ${ }^{73}$ Teaching with technology is no different in this regard. Numerous literature surveys link student technology achievement to teachers' opportunities to develop their own computer skills. ${ }^{74}$ Yet teachers commonly are required to devote almost all of their time to solo preparation and performance, with little time available for training in the use of technology.75

Technology itself, however, is proving to be a powerful tool in helping teachers 
bridge the gap in training on effective use of computers. ${ }^{14}$ By networking with mentors and other teachers electronically, teachers can overcome the isolation of the classroom, share insights and resources, support one another's efforts, and engage in collaborative projects with similarly motivated teachers. Teachers also gain valuable experience by using computers for their own needs.

Teachers who succeed in using technology often make substantial changes in their teaching style and in the curriculum they use. H owever, making such changes is difficult without appropriate support and commitment from school administration.

\section{Cunic ulum Modemization}

The type of curriculum a school adopts has a significant impact in determining the extent to which computer-based technologies can be integrated effectively into the classroom. On the one hand, many parents and educators believe that students should master basic skills before they are exposed to challenging content, and computer technology can be used to support a curriculum with this emphasisthrough drill-and-practice applications. On the other hand, many learning researchers argue that the most effective way of promoting learning is to embed basic skills instruction within more complex tasks. They advocate adopting a curriculum that teaches the higher-order skills of reasoning, comprehension, and design in tandem with the basic skills of computation, word decoding, and language mechanics. 76 Because computer technology has been most effective when used to support the learning of these more complex skillsand concepts, computer-based technology can be integrated most effectively into a curriculum that embraces this tandem approach.

National associations and research institutions have called for challenging content to prepare students for the twenty-first century. ${ }^{77}$ To date, some progress has been made in setting more challenging goals in national standards and state curriculum framework documents, especially in the areas of science and mathematics. The National Council of Teachers of Mathematics K-12 standards often are cited as an example of a sensible and widely implemented set of goals, 78 and many experiments with technology are now oriented toward helping meet http:// www. futu reofchildren.org these standards. Progress also has been made in setting more challenging goals for science learning, 3 but less progress has been made in updating goals in other subject areas. Strategies for effective, broad-scale adoption of particular technologies are dependent on progress in adopting more challenging national and statewide goals by community stakeholders, including teachers, parents, school boards, and administrators.

\section{Sudent Assessment and \\ Evaluation}

One of the biggest barriers to introducing effective technology applications in classrooms is the heavy focus on student performance on district- or state-mandated assessments and the mismatch between the content of those assessments and the kinds of higher-order learning supported most effectively by technology.79 This mismatch leads to less time available for higher-order

\section{One of the biggest barriers to introducing effective technology applications in classrooms is the mismatch between the content of assessments and the kinds of higher-order learning supported most effectively by technology.}

instruction and less appreciation of the impact technology can have on learning. Time spent preparing students to do well on numerical calculation tests, vocabulary, or English mechanics cannot be spent on learning about acceleration, the mathematics of change, or the structure of Shakespeare's plays. Moreover, it will be difficult, if not impossible, to demonstrate the contribution of technologies in developing students' abilities to reason and understand concepts in depth without new kinds of assessments. As noted earlier, compared with peers who learned algebra through conventional methods, urban high school students using a computer-based algebra tutor system performed much better on tests that stressed their ability to think creatively about a complex problem over a longer time period, but showed only a small advantage on standardized tests that do not adequately measure such higher-order thinking skills.45,80 Although it is challenging to 
develop ways to measure student understanding of complex concepts and higherorder thinking skills, current research on the effectiveness of selected computer-based applications may provide strategies that could be considered for adoption in future educational assessment frameworks. ${ }^{81}$

\section{Capacity for Change}

Systematic studies of schools that have implemented educational reforms provide useful information about the organizational dynamics of significant change and the role computer technology can play in this process. In a series of cross-sectional case studies conducted in 1995, several key factors associated with effective use of technology in schools were identified:82

\section{To help inform future decisions about improving how and what students learn, further explorations of effective use of technology are needed.}

- Technology access and technical support;

- Instructional vision and a rationale linking the vision to technology use;

- Critical mass of teachers in technology activities;

- High degree of collaboration among teachers;

\section{- Strong leaders; and}

- Support for teacher time for planning, collaboration, and reporting technology use.

These findings were echoed more recently in a 1998 survey of more than 4,000 teachers, who identified these key factors affecting school computer use: (1) location and number of computers available to a class, (2) teacher computer expertise, (3) teacher philosophy and objectives, and (4) school culture (see the article by Becker in this journal issue).

Specifically, this survey found that Internet use is more common in schools where teachers talk to their colleagues and have the opportunity to visit each other's classrooms. ${ }^{83}$ In fact, such teacher-to-teacher interaction was more strongly associated with Internet use than was participation in training on how to use the Internet. These studies suggest that the relationship between technology use and education reform is reciprocal: although technology use helps support school change, school change efforts also help support effective use of technology.84

\section{Conclusions and Policy Implications}

Using technology to improve education is not a simple matter. There are manykinds of technology and many ways that an attempted use can fail. From a policy perspective, it would be desirable to have clear and broadly generalizable measures of effectiveness before committing to continual investments in technology. Such data might take the form "for every $\mathrm{x} \%$ of a school budget reallocated to technology, student learning will improve by $\% \%$." U nfortunately, the existing research falls short of providing such clear measures of effectiveness. Even so, many policymakers, parents, and educators are rapidly moving ahead to introduce computers into the classroom. The challenge is to ensure this technology is used effectively to enhance how and what children learn.

To help inform future decisions about improving how and what students learn, further explorations of effective use of technology are needed. The continuum of explorations for educational improvement stretches from basic research on learning with technology to applied research looking at the classroom practicalities of improving teaching when technology is a component. These explorations, whether carried out by schools, individual teachers, university researchers, or others, should be executed with a reflective research component so that the knowledge gained can add to the rational basis used for making effective decisions. Four factors can be used to guide these future explorations:

- Cognitive learning. Much more is currently known about how children learn than was known a century ago. Technology applications selected for future research should engage the cognitive characteristics of learning as a constructive, collaborative, interactive, contextualized process. 
- Curricular reforms. Given the societal pressure for individuals to know more than ever before, it is particularly important to explore technology adopted in tandem with curricular reforms that make complex subject matter accessible to a higher percentage of children.

- Coordinated interventions. Successful implementation of technology requires a context of coordinated interventions to improve curricula, assessment, teacher development, and all the other pieces of the education jigsaw puzzle. Explorations of technology implementations should focus on schools that are striving to have all these pieces of the puzzle in place.

- Capacity for change. Today's schools are not all equally prepared to accept technology and use it to improve student learning. For improvements that include technology to take hold, schools need to develop their capacity for change with appropriate resources and processes that enable all the involved parties to manage the challenging transition. Thus, effective uses of technology should be explored in schools that are well prepared for change.

To maximize the effectiveness of computer technology as a tool to enhance learning in the classroom, education policymakers must incorporate technology selectively into educational reform as part of an overall program for improvement and continue to study its progress and results to improve efforts over time. Using the four factors outlined here, research can help target initial applications of technology that are most likely to improve learning within overall programs of experimental reform.

1. U.S. Department of Education, National Center for Education Statistics. The condition of education 1996. Supplemental table 29-6. Washington, DC: U.S. Government Printing Office, 1996. Available online at http:/ / nces.ed.gov/ pubsold/ ce96/ c9629d06.html.

2. Resnick, D.P., and Resnick, L.B. The nature of literacy: A historical exploration. Harvard Educational Review (1977) 457:370-85; Wolf, D.P. Becoming literate. Academic Connections: The College Board (1988) 1:4.

3. National Research Council. National science education standards. Washington, DC: N ational Academy Press, 1996.

4. For example, see the report from the President's Information Technology Advisory Committee. Information technology research: Investing in our future. Arlington, VA: National Coordination Office for Computing, Information, and Communication, February 1999. Available online at http:/ / www.ccic.gov/ ac/ report/ .

5. Kaput, J., and Roschelle, J. The mathematics of change and variation from a millennial perspective: New content, new context. In Rethinking the mathematics curriculum. C. Hoyles, C. Morgan, and G. Woodhouse, eds. London: Falmer Press, 1998.

6. National Council for Accreditation of Teacher Education. Technology and the new professional teacher: Preparing for the 21st century classroom. Washington, DC: NCATE, 1997. Available online at http:/ / www.ncate.org/ accred/ projects/ tech/ tech-21.htm; U.S. Department of Education, National Center for Education Statistics. Advanced telecommunications in U.S. public elementary and secondary schools, Fall 1996. Washington, DC: U.S. Department of Education, February 1997. Available online at http:/ / nces.ed.gov/ pubs/ 97944.html; U.S. Department of Education, National Center for Education Statistics. Internet access in public schools, issue brief. Washington, DC: U.S. Department of Education, February 1998. Available online at http:/ / nces.ed.gov/ pubs98/ 98031.html; U.S. Congress, O ffice of Technology Assessment. Teachers and technology: M aking the connection. Washington, DC: U.S. Government Printing Office, April 1995; President's Committee of Advisors on Science and Technology, Panel of Educational Technology. Report to the President on the use of technology to stren gthen $\mathrm{K}-12$ education in the United States. Washington, DC: PCAST, Executive Office of the President of the United States, March 1997. Available online at http:/ / www.whitehouse.gov/ WH/ EOP/ OSTP/ NSTC/ PCAST/ k-12ed.html.

7. Cuban, L. Teachers and machines: The classroom uses of technology since 1920. New York: Teachers College Press, 1986; see also Tyack, D., and Cuban, L. Tinkering toward utopia: A century of public school reform. Cambridge, MA: Harvard University Press, 1995.

8. White H ouse Publications Service. From digital divide to digital opportunity: A strong record of working to close the digital divide. February 2,2000. Available online at http:/ / www.whitehouse.gov/ WH/ New/ digitaldivide/ index.html. 
9. See note no. 6, President's Committee of Advisors on Science and Technology.

10. Sivin-Kachala, J., and Bialo, E.R. 1999 research report on the effectiveness of technology in schools. 6th ed. Washington, DC: Software and Information Industry Association, 1999.

11. Schacter, J. The impact of education technology on student achievement: What the most current research has to say. Santa Monica, CA: Milken Exchange on Education Technology, 1999.

12. Wenglinsky, H. Does it compute? The relationship between educational technology and student achieve ment in mathematics. Princeton, NJ: Educational Testing Service, 1998.

13. Kulik, J.A. Meta-analytic studies of findings on computer-based instruction. In Technology assessment in education and training. Hillsdale, NJ: Lawrence Erlbaum Associates, 1994.

14. Bransford, J.D., Brown, A.L., and Cocking, R.R., eds. H ow people learn: B rain, mind, experience and school. Washington, DC: National Academy Press, 1999.

15. Greeno, J., Collins, A., and Resnick, L.B. Cognition and learning. In H andbook of educational psychology. D.C. Berliner and R.C. Calfee, eds. New York: Macmillan Library Reference, 1996.

16. This phenomenon is often referred to as the "transfer problem." See Bransford, J.D., and Schwartz, D.L. Rethinking transfer: A simple proposal with interesting implications. In Review of research in education, 24. Washington, DC: American Educational Research Association, 1999.

17. Gardner, H. M ultiple intelligences: The theory in practice. N ew York: Basic Books, 1993.

18. Learning has been conceptualized by various education theoreticians primarily as problem solving. See, for example, Newell, A., and Simon, H.A. H uman problem solving. Englewood Cliffs, NJ: Prentice-H all, 1972; as inquiry, see, for example, Dewey, J. The child and the curriculum. In The philosophy of John Dewey, Vol. II: The lived experience. J.J. McDermott, ed. New York: G.P. Putnam's Sons, 1902, pp. 467-83; as sense-making see, for example, Piaget, J. Play, dreams, and imitation in childhood. New York: W.W. Norton, 1962; as intellectual socializing see, for example, Vygotsky, L.S. M ind in society. Cambridge, MA: H arvard University Press, 1978; and as design see, for example, Perkins, D.N. Knowledge as design. Hillsdale, NJ: Lawrence Erlbaum Associates, 1986.

19. Bruer, J. Schools for thought. Cambridge, MA: MIT Press, 1993.

20. Svec, M.T. Effect of microcomputer-based laboratory on students' graphing interpretation skills and conceptual understanding of motion. Ph.D. Dissertation, Indiana University, Bloomington, IN, Department of Education, June 1994; Thornton, R.K., and Sokoloff, D.R. Learning motion concepts using real-time microcomputer-based laboratory tools. A merican Journal of Physics (1990) 58:858-66.

21. Mokros, J.R., and Tinker, R.F. The impact of microcomputer-based labs on children's ability to interpret graphs. Journal of Research in Science Teaching (1987) 24:369-83.

22. Nachmias, R., and Linn, M.C. Evaluations of science laboratory data: The role of computerpresented information. Journal of R esearch in Science Teaching (1987) 24:491-506. Students participating in MBLs showed significant gains in their ability to discern errors in graphs because of the graph scale and experimental variation, no gains in ability to discern errors because of probe setup and calibration, and declines in their ability to discern errors because of probe sensitivity.

23. Liu, M., and Rutledge, $K$. The effect of a "learner as multimedia designer" environment on at-risk high school students' motivation and learning of design knowledge. Journal of Educational Computing Research (1997) 16:145-77; Liu, M. A study of engaging high-school students as multimedia designers in a cognitive apprenticeship-style learning environment. Computers in H uman Behavior (August 1998) 14:387-415. See note no. 10, Sivin-Kachala and Bialo, pp. 69-70, for a summary of these studies.

24. See note no. 18, Vygotsky. See also Newman, D., Griffin, P., and Cole, M. The construction zone: Working for cognitive change in school. N ew York: Cambridge University Press, 1989; Rogoff, B. A pprenticeship in thin king: Cognitive development in social context. New York: Oxford U niversity Press, 1990.

25. Lave, J., and Wenger, E. Situated learning: Legitimate peripheral participation. New York: Cambridge University Press, 1991.

26. Harasim, L., Hiltz, S.R., Teles, L., et al. Learning networks. Cambridge, MA: MIT Press, 1995.

27. Goldman, S.R., Petrosino, A.J., Sherwood, R.D., et al. Anchoring science in multimedia learning environments. In International perspectives on the psychological foundations of technologybased learning environments. S. Vosniadou, E. De Corte, R. Glaser, and H. Mandl, eds. Hillsdale, NJ: Lawrence Erlbaum Associates, 1996. For a systematic analysis of distributed multimedia 
learning environments, see Pea, R.D., and Gomez, L. Distributed multimedia learning environments: Why and how? Interactive Learning Environments (1992) 2:73-109.

28. CSILE was started by Marlene Scardamalia and Carl Bereiter at the Ontario Institute for Studies of Education. This technology, originally developed in a research setting, is now part of a national Canadian initiative called Telelearning Centres of Excellence, which will commercialize and disseminate the technology. See Scardamalia, M., Bereiter, C., McLean, R.S., et al. Computer supported intentional learning environments. Journal of Educational Computing Research (1989) 5:51-68; Scardamalia, M., and Bereiter, C. Computer support for knowledge-building communities. The Journal of the Learning Sciences (1994) 3:265-83.

29. Gains have also been found for students participating in CSILE projects at the university level. See, for example, Scardamalia, M., and Bereiter, C. Technologies for knowledge-building discourse. Communications of the ACM (1993) 36:37-41; Scardamalia, M., and Bereiter, C. Computer support for knowledge-building communities. In CSCL: T heory and practice of an emerging paradigm. T. Koschmann, ed. Mahwah, NJ: Lawrence Erlbaum Associates, 1996.

30. Bryson, M., and Scardamalia, M. Teaching writing to students at risk for academic failure. In Teaching advanced skills to at-risk students: Views from research and practice. B. Means, C. Chelemer, and M.S. Knapp, eds. San Francisco: Jossey-Bass, 1991, pp. 141-67.

31. Riel, M. Learning circles: A functional analysis of educational telecomputing. Interactive Learning Environments (1992) 2:15-30.

32. H oadley, C.M., H si, S., and Berman, B.P. The Multimedia Forum Kiosk and SpeakEasy. In Proceedings of ACM M ultimedia '95. New York: ACM Press, 1995.

33. H si, S., and Hoadley, C.M. Productive discussion in science: Gender equity through electronic discourse. Journal of Science Education and Technology (1997) 6:23-36.

34. Schank, P., Ranney, M., H oadley, C.M., et al. A reasoner's workbench for improving scientific thinking: Assessing Convince Me. In Proceedings of the 1994 International Symposium on M athematics/ Science Education and Technology. G.H. Marks, ed. Charlottesville, VA: AACE, 1994; see also Suthers, D., Toth, E.E., and Weiner, A. An integrated approach to implementing collaborative inquiry in the classroom. In Proceedings of the Conference on Computer Supported Collaborative Learning 1997. Toronto, Ontario: CSCL, December 10-14, 1997.

35. Weir, S. Electronic communities of learners: Fact or fiction. TERC Working Paper 3-92. Cambridge, MA: TERC Communications, January 1992.

36. Pimm D. Speaking mathematically - communication in mathematics classrooms. London: Routledge, 1987.

37. Anderson, J.R. The architecture of cognition. Mahwah, NJ: Lawrence Erlbaum Associates, 1996.

38. Schofield, J.W. Computers and classroom culture. New York: Cambridge University Press, 1995.

39. Anderson, J.R., Corbett, A.T., Koedinger, K., et al. Cognitive tutors: Lessons learned. The Journal of the Learning Sciences (1995) 4:167-207.

40. See note no. 10, Sivin-Kachala and Bialo, pp. 31-33.

41. Clark, H.C. Cyber-coaching in computer as learning partner. Paper presented at the Annual Meeting of the American Educational Research Association. New York, April 8-12, 1996.

42. Studies indicate, however, that the success of feedback programs is linked to telling students why their answers are wrong, not just what answers are wrong. See note no. 10, Sivin-Kachala and Bialo, pp. 31-33.

43. Hunt, E., and Minstrell, J. A cognitive approach to the teaching of physics. In Classroom lessons: Integrating cognitive theory and dassroom practice. K. McGilly, ed. Cambridge, MA: MIT Press, 1994, pp. 51-74.

44. Wertheimer, R. The geometry proof tutor: An "intelligent" computer-based tutor in the classroom. M athematics Teacher (1990) 83:308-17.

45. Koedinger, K.R., Anderson, J.R., H adley, W.H., et al. Intelligent tutoring goes to school in the big city. International Journal of Artificial Intelligence in Education (1997) 8:30-43.

46. Gore, A. Earth in the balance: Ecology and the human spirit. New York: Plume, 1992.

47. NOAA National Geophysical Data Center. GLOBE year 3 evaluation. 1999. Available online at http:/ / www.globe.gov/ sda-bin/ wt/ ghp/ y3eval tL(en).

48. For more information, see the Global Lab Curriculum Web site at http:/ / globallab.terc.edu/ .

49. For more information, see the Jason Project Web site at http:/ / www.jasonproject.org/ .

50. For more information, see the KidSat Web site at http:// kidsat.JPL.NASA.GOV/ . 
51. Cognition and Technology Group at Vanderbilt. Looking at technology in context: A framework for understanding technology and education research. In H andbook of educational psychology. D.C. Berliner and R.C. Calfee, eds. New York: Macmillan Library Reference, 1996; see also Barron, B.J., Schwartz, D.L., Vye, N.J., et al. Doing with understanding: Lessons from research on problem- and project-based learning. Journal of Learning Sciences (1998) 7:271-311.

52. Smith, J.P., diSessa, A.A., and Roschelle, J. Misconceptions reconceived: A constructivist analysis of knowledge in transition. Journal of the Learning Scien ces (1993) 3:115-63.

53. Gordin, D., and Pea, R.D. Prospects for scientific visualization as an educational technology. The Journal of the Learning Sciences (1995) 4:249-79.

54. White, B.Y. ThinkerTools: Causal models, conceptual change, and science education. Cognition and Instruction (1993) 10:1-100. Interactive Physics is a commercial product that works along similar lines; it is used by professional physicists as both a teaching tool and to simulate real-world physics problems.

55. White, B.Y., and Fredriksen, J.R. Inquiry, modeling, and metacognition: Making science accessible to all students. Cognition and Instruction (1998) 16:63, 90-91.

56. Doerr, H.M. Stella ten years later: A review of the literature. International Journal of Computers for M athematical Learning (1996) 1:201-24.

57. Resnick, M. Turtles, termites, and traffic jams: Explorations in massively paralle microworlds. Complex Adaptive Systems series. Cambridge, MA: MIT Press, 1997.

58. Pea, R.D., Gomez, L.M., Edelson, D.C., et al. Science education as a driver of cyberspace technology development. In Internet links for science education. K.C. Cohen, ed. N ew York: Plenum Press, 1997, pp. 189-220; see also Songer, N.B. Exploring learning opportunities in coordinated network-nhanced classrooms: A case of kids as global scientists. Journal of the Learning Sciences (1996) 5:297-327.

59. Schmidt, W.H., McKnight, C.C., Valverde, G.A., et al. M any visions, many aims: A cross-national investigation of curricular intentions in school mathematics. Vol. 1, Third International Mathematics and Science Study. Hingham, MA: Kluwer Academic Publishers, 1997.

60. Kaput, J. Technology and mathematics education. In A handbook of research on mathematics teaching and learning. D. Grouws, ed. New York: MacMillan, 1992, pp. 515-56.

61. Roschelle, J., and Kaput, J. SimCalc MathWorlds for the mathematics of change. Communications of the ACM (1996) 39:97-99.

62. Jackiw, N. The geometer's sketchpad. Computer software. Berkeley, CA: Key Curriculum Press, 1988-2000. This software, available in various versions, aids in the teaching and study of geometry. For more information, see Web site at http:/ / www.keypress.com.

63. The H eller Reports. The state of Virginia purchases graphing calculators for all algebra students. The H eller Report on Educational Technology M arkets (January 1998).

64. Friedlander, L. The Shakespeare project: Experiments in multimedia education. In $H$ ypermedia and literary studies. G. Landow and P. Delany, eds. Cambridge, M A: MIT Press, 1991, pp. 257-71.

65. Spiro, R.J., Feltovich, P.J., Jacobson, M.J., et al. Cognitive flexibility, constructivism, and hypertext: Random access instruction for advanced knowledge acquisition in ill-structured domains. In Constructivism and the technology of instruction: A conversation. T.M. Duffy and D.H . Jonassen, eds. Hillsdale, NJ: Lawrence Erlbaum Associates, 1992, pp. 57-75.

66. Crane, G. Building a digital library: The Perseus Project as a case study in the humanities. In Digital libraries 1996: Procedings of the 1st ACM international conference on digital libraries. E.A. Fox and G. Marchionini, eds. N ew York: ACM, 1996, pp. 3-10. Available online at http:/ / www.perseus.tufts.edu.

67. Ferretti, R.P., and Okolo, C.M. Designing multimedia projects in the social studies: Effects on students' content knowledge and attitudes. Paper presented at the Annual Meeting of the American Educational Research Association. Chicago, March 1997. See note no. 10, Sivin-Kachala and Bialo, p. 18, for a summary.

68. Schultz, L.H. Pilot validation study of the Scholastic Beginning Literacy System (Wiggle Works) 1994-95 midyear report. U npublished paper. February 1995. See note no. 10, Sivin-Kachala and Bialo, p. 8, for a summary.

69. Bamberger, J. The mind behind the $\mathrm{H}$ : $\mathrm{H}$ ow children develop musical intelligence. Cambridge, MA: H arvard U niversity Press, 1991. 
70. Eisenberg, M., and Nishioka, A. Orihedra: Mathematical sculptures in paper. International Journal of Computers for M athematical Learning (1997) 1:225-61.

71. McClurg, P., Lee, J., Shavalier, M., and Jacobsen, K. Exploring children's spatial visual thinking in an HyperGami environment. In Vision Quest: Journeys toward visual literacy. Selected readings from the 28th Annual Conference of the International Visual Literacy Association. ERIC no. ED408976. Washington, DC: Educational Resources Information Center, January 1997.

72. David, J. Realizing the promise of technology. In Technology and education reform. B. Means, ed. San Francisco: Jossey-Bass, 1994, pp. 169-80.

73. Shulman, L.S. Knowledge and teaching foundations of the new reform. $\mathrm{H}$ arvard Education Review (1987) 57:1-22; see also Stodolsky, S. Thesubject matters: Classroom activity in math and social studies. Chicago: University of Chicago Press, 1988.

74. See note no. 6, President's Committee of Advisors on Science and Technology; see also note no. 14, Bransford, Brown, and Cocking.

75. Corcoran, T.B. Transforming professional development for teachers: A guide for state policymakers. Washington, DC: National Governors Association, 1995.

76. Resnick, L.B. Instruction and the cultivation of thinking. In $\mathrm{H}$ andbook of educational ideas and practice. J. Entwistle, ed. London: Routledge, 1990, pp. 694-707.

77. Learning First Alliance. Learning First Alliance goals. 1999. Available online at http:/ / www.learningfirst.org/ . The Learning First Alliance member organizations include the American Association of Colleges for Teacher Education, American Association of School Administrators, American Federation of Teachers, Association for Supervision and Curriculum Development, Council of Chief State School O fficers, Education Commission of the States, National Association of Elementary School Principals, National Association of Secondary School Principals, National Association of State Boards of Education, National Education Association, National Parent Teacher Association, and National School Boards Association.

78. National Council of Teachers of Mathematics. Curriculum and evaluation standards for school mathematics. Washington, DC: NCTM, 1989.

79. Means, B. Models and prospects for bringing technology-supported educational reform to scale. Paper presented at the annual meeting of the American Educational Research Association. San Diego, April 1998.

80. Koedinger, K.R., and Sueker, E.L.F. PAT goes to college: Evaluating a cognitive tutor for developmental mathematics. In Proceedings of the Second International Conference on the L earning Sciences. Charlottesville, VA: Association for the Advancement of Computing in Education, 1996, pp. 180-87.

81. Center for Innovative Learning Technologies. Technology supports for improved assessments. Manuscript commissioned by the National Education Association. In press.

82. Means, B., and Olson, K. Technology's role in education reform: Findings from a national study of innovating schools. Menlo Park, CA: SRI International, 1995.

83. Becker, H.J. Teaching, learning, and computing: 1998 survey. Available online at http:/ / www.crito.uci.edu/ TLC/ html/ tlc_home.html.

84. Means, B. Introduction: U sing technology to advance educational goals. In Technology and education reform. B. Means, ed. San Francisco: Jossey-Bass, 1994, pp. 1-21.

(Table 1 follows on pp. 98-101.) 
Table 1

\section{Major Studies on the Effectiveness of Computers as Leaming Tools}

\begin{tabular}{|c|c|c|c|}
\hline Study & Participants & Design and Methods & Findings \\
\hline $\begin{array}{l}\text { Baker, E.L, Gea rha rt, M., a nd } \\
\text { Herman, J.L Evaluating the } \\
\text { Apple classrooms of tomomow. } \\
\text { Technology assessment in } \\
\text { education and tra ining. } \\
\text { Hillsdale, NJ : La wrence } \\
\text { Erbaum Associates, } 1994 .\end{array}$ & $\begin{array}{l}\text { First through } \\
\text { twelfth graders }\end{array}$ & $\begin{array}{l}\text { Series of evaluation studies over a } \\
\text { three-year period. Students and } \\
\text { teachers were given Apple com- } \\
\text { puters in the classroom and at } \\
\text { home. Compa rison groups in } \\
\text { neighboring a reas were chosen. } \\
\text { Study conducted in five school } \\
\text { sites located in Ca lifomia, Ohio, } \\
\text { Minnesota, and Tennessee. }\end{array}$ & $\begin{array}{l}\text { - Apple Computers of } \\
\text { Tomorrow (ACOT) had } \\
\text { a positive impact on } \\
\text { student attitudes. } \\
\text { - Overall, ACOTstudents } \\
\text { did not perform better } \\
\text { on standardized tests. }\end{array}$ \\
\hline $\begin{array}{l}\text { Bangert-Drowns, R.L The } \\
\text { word processor as an } \\
\text { instructional tool: A meta- } \\
\text { a na lysis of word processing } \\
\text { in writing instruction. Review } \\
\text { of Educational Research } \\
\text { (1993) 63:63-93. }\end{array}$ & $\begin{array}{l}\text { Elementary school } \\
\text { age through } \\
\text { college age }\end{array}$ & $\begin{array}{l}\text { Meta-a na lysis ba sed on } \\
32 \text { comparative studies } \\
\text { measuring posttreatment } \\
\text { performa nce criteria such as } \\
\text { quality of writing, number } \\
\text { of words, attitude towa rd } \\
\text { writing, a dherence to writing } \\
\text { conventions, a nd frequency } \\
\text { of revision. }\end{array}$ & $\begin{array}{l}\text { - Small effect on improvement } \\
\text { of writing skills. } \\
\text { - Studies that focused on } \\
\text { word processing in the } \\
\text { context of remedial writing } \\
\text { yielded a la rger effect. }\end{array}$ \\
\hline $\begin{array}{l}\text { Clements, D.H. Enhancement } \\
\text { of creativity in computer } \\
\text { environments. American } \\
\text { Educational Research J oumal } \\
\text { (1991) 28:173-87. }\end{array}$ & $\begin{array}{l}73 \text { third graders- } \\
\text { (mean age } 8 \text { years, } \\
8 \text { months) }\end{array}$ & $\begin{array}{l}\text { Pretest, posttest design over } \\
\text { a } 25 \text {-week period. Child ren } \\
\text { matched on creativity and } \\
\text { a chievement were assigned } \\
\text { to (1) Logo softwa re, (2) non- } \\
\text { computer creativity training, } \\
\text { or (3) control. Study took place } \\
\text { in New York. }\end{array}$ & $\begin{array}{l}\text { - Children who worked with } \\
\text { Logo had increased figural } \\
\text { (nonverbal) creativity. } \\
\text { - Both Logo and non- } \\
\text { computer activities } \\
\text { increased children's } \\
\text { verbal creativity. }\end{array}$ \\
\hline $\begin{array}{l}\text { Fletc her, J .D., Ha wley, D.E., and } \\
\text { Piele, P.K. Costs, effects, } \\
\text { and utility of mic rocomputer- } \\
\text { a ssisted instruction in the } \\
\text { classroom. Pa per presented } \\
\text { at the 7th Intemational } \\
\text { Conference on Tec hnology } \\
\text { and Educ ation. Brussels, } \\
\text { Belgium, } 1999 .\end{array}$ & $\begin{array}{l}\text { Third and fifth } \\
\text { graders }\end{array}$ & $\begin{array}{l}\text { Students at grade level } \\
\text { received either computer- } \\
\text { assisted instruction (CAI) or } \\
\text { tra ditional math instruction } \\
\text { for } 71 \text { days. }\end{array}$ & $\begin{array}{l}\text { - At both grade levels, students } \\
\text { receiving CAI scored higher } \\
\text { on a test of basic math } \\
\text { skills than those who rec eived } \\
\text { traditional instruction only. }\end{array}$ \\
\hline $\begin{array}{l}\text { Fletc her-Flinn, C.M., and } \\
\text { Gravatt, B. The effica cy of } \\
\text { computer a ssisted instruction } \\
\text { (CAI): A meta-a na lysis. J oumal } \\
\text { of Educationa I Computing } \\
\text { Research (1995) 12:219-42. }\end{array}$ & $\begin{array}{l}\text { Students from } \\
\text { kindergarten } \\
\text { through higher } \\
\text { education }\end{array}$ & $\begin{array}{l}\text { Meta-a na lysis of } 120 \text { studies } \\
\text { conducted between } 1987 \text { and } \\
\text { 1992. Looked at a range of } \\
\text { factors including educational } \\
\text { level, c ourse content, publication } \\
\text { year, duration of study, same } \\
\text { or different tea cher for the } \\
\text { control group, and type of CAI. }\end{array}$ & $\begin{array}{l}\text { - No signific ant differences in } \\
\text { study results for any of the } \\
\text { factors. } \\
\text { - Gains in profic iency linked } \\
\text { with only one factor: the } \\
\text { quality of CAI materials. }\end{array}$ \\
\hline
\end{tabular}


Table 1 (continued)

\section{Major Studies on the Effectiveness of Computers as Leaming Tools}

\begin{tabular}{|c|c|c|c|}
\hline Study & Participants & Design and Methods & Findings \\
\hline $\begin{array}{l}\text { Foster, K., Eric kson, G., Foster, D., } \\
\text { et al. Computer-administered } \\
\text { instruction in phonological } \\
\text { awareness: Evaluation of the } \\
\text { Daisy Quest program. } \\
\text { Unpublished paper. }\end{array}$ & $\begin{array}{l}\text { Prekinderga rten } \\
\text { and kind ergarten } \\
\text { child ren; } 25 \text { in first } \\
\text { study; } 70 \text { in second } \\
\text { study }\end{array}$ & $\begin{array}{l}\text { Pretest, posttest design. } \\
\text { Children randomly assigned to } \\
\text { experimental group or control } \\
\text { group. Experimental group } \\
\text { received } 16 \text { to } 20 \text { sessions with } \\
\text { DaisyQuest-a computerized } \\
\text { program designed to } \\
\text { increa se phonologic al } \\
\text { a wareness. }\end{array}$ & $\begin{array}{l}\text { In two different studies and } \\
\text { five different measures of } \\
\text { phonological a wareness, the } \\
\text { computer-based approach } \\
\text { was found to be more } \\
\text { effective than regular } \\
\text { instruction. }\end{array}$ \\
\hline $\begin{array}{l}\text { Gardner, C.M., Simmons, P.E., } \\
\text { and Simpson, R.D. The effects of } \\
\text { CAl and hands-on a ctivities on } \\
\text { elementary students' attitudes } \\
\text { and weather knowledge. } \\
\text { School Science and } \\
\text { Mathematics (1992) 92: } \\
\text { 334-36. }\end{array}$ & Third graders & $\begin{array}{l}\text { Comparative study of three } \\
\text { groups in Georgia. First } \\
\text { group received hands-on } \\
\text { meteorology a ctivities } \\
\text { combined with software; } \\
\text { second group received } \\
\text { hands-on activities without } \\
\text { software; and third group } \\
\text { received tra ditional } \\
\text { classroom instruction. }\end{array}$ & $\begin{array}{l}\text { Children who had hands-on } \\
\text { with softwa re outperformed } \\
\text { those who had hands-on } \\
\text { without software. } \\
\text { - Both groups scored higher } \\
\text { than those who had } \\
\text { traditional instruction. }\end{array}$ \\
\hline $\begin{array}{l}\text { Kulik, J.A. Meta-a na lytic studies } \\
\text { of findings on computer-ba sed } \\
\text { instruction. In Technology } \\
\text { assessment in education } \\
\text { and training. Hillsdale, NJ : } \\
\text { Lawrence Erlbaum } \\
\text { Assoc iates, } 1994 .\end{array}$ & $\begin{array}{l}\text { Students from } \\
\text { kindergarten } \\
\text { through higher } \\
\text { education }\end{array}$ & $\begin{array}{l}\text { Meta-analysis of more than } 500 \\
\text { ind ividual stud ies of computer- } \\
\text { based instruction. }\end{array}$ & $\begin{array}{l}\text { - Students who used } \\
\text { computer-based instruction } \\
\text { scored higher on } \\
\text { achievement tests, leamed } \\
\text { in less time, and were } \\
\text { more likely to develop } \\
\text { positive attitudes. }\end{array}$ \\
\hline $\begin{array}{l}\text { Laza rowitz, R., a nd Hup pert, J. } \\
\text { Science process skills of 10th } \\
\text { grade biology students in a } \\
\text { computer-assisted leaming } \\
\text { setting. J oumal of Research on } \\
\text { Computing in Education (1993) } \\
\text { 25:366-82. }\end{array}$ & High school students & $\begin{array}{l}\text { Pretest, posttest design } \\
\text { over four weeks in five biology } \\
\text { classes in Israel. The experimental } \\
\text { group rec eived classroom } \\
\text { la boratory instruction that } \\
\text { included use of a software } \\
\text { program. The control group } \\
\text { received classroom } \\
\text { instruction only. }\end{array}$ & $\begin{array}{l}\text { - Experimental group achieved } \\
\text { higher mean score on the } \\
\text { posttest. } \\
\text { - No signific ant differences } \\
\text { between the groups by } \\
\text { gender. }\end{array}$ \\
\hline $\begin{array}{l}\text { Mann, D., Shakesshaft, C., } \\
\text { Becker, ., et al. West Virginia's } \\
\text { Basic Skills/Computer } \\
\text { Education program: An } \\
\text { analysis of achievement. } \\
\text { Santa Monica, CA: Milken } \\
\text { Family Foundation, } 1999 .\end{array}$ & $\begin{array}{l}\text { Representative } \\
\text { sample of } 950 \text { fifth- } \\
\text { grade students from } \\
18 \text { elementary } \\
\text { schools }\end{array}$ & $\begin{array}{l}\text { Study of students who used } \\
\text { Basic Skills/Computer Education } \\
\text { program in West Virginia. } \\
\text { Several varia bles were a na lyzed, } \\
\text { including intensity of use, prior } \\
\text { achievement soc iodemogra phy, } \\
\text { teacher training, and tea cher } \\
\text { and student attitudes. }\end{array}$ & $\begin{array}{l}\text { - The more students } \\
\text { partic ipated in the program, } \\
\text { the more their test scores } \\
\text { improved. } \\
\text { - Consistent access, positive } \\
\text { attitudes toward the } \\
\text { equipment, and teacher } \\
\text { training in the technology led } \\
\text { to the greatest achievement } \\
\text { gains. }\end{array}$ \\
\hline
\end{tabular}


Table 1 (continued)

\section{Major Studies on the Effectiveness of Computers as Leaming Tools}

\begin{tabular}{|c|c|c|c|}
\hline Sudy & Participants & Design and Methods & Findings \\
\hline $\begin{array}{l}\text { Mayfield-Stewart, C., Morre, P., } \\
\text { Sharp, D., et al. Evaluation of } \\
\text { multimedia instruction on } \\
\text { leaming and transfer. Paper } \\
\text { presented at the Annual } \\
\text { Conference of the Americ an } \\
\text { Education Research. } \\
\text { New Orleans, } 1994 \text {. }\end{array}$ & $\begin{array}{l}\text { At-risk, inner-city } \\
\text { kindergartners }\end{array}$ & $\begin{array}{l}\text { Children exposed to a } \\
\text { multimedia environment } \\
\text { (Multimedia Environments that } \\
\text { Organize and Support Text) for } \\
\text { language development for } \\
\text { three months were compared } \\
\text { with children in a conventional } \\
\text { kindergarten classroom. }\end{array}$ & $\begin{array}{l}\text { Study group showed superior } \\
\text { gains in auditory skills and } \\
\text { language skills, were able } \\
\text { to tell stories better, and } \\
\text { showed better use of tense. }\end{array}$ \\
\hline $\begin{array}{l}\text { Nastasi, B.K., Clements, D.H., } \\
\text { and Battista, M.T.Social- } \\
\text { cognitive interactions, } \\
\text { motivation, and cognitive } \\
\text { growth in Logo programming } \\
\text { and CAI problem-solving } \\
\text { environments. J oumal of } \\
\text { Educational Psychology } \\
\text { (1990) 82:150-58. }\end{array}$ & $\begin{array}{l}12 \text { fourth graders } \\
\text { and } 28 \text { sixth } \\
\text { graders }\end{array}$ & $\begin{array}{l}\text { Pretest, posttest design over } \\
22 \text { weeks. Pa irs of students } \\
\text { were randomly a ssigned to } \\
\text { either Logo ac tivities or CAI } \\
\text { problem-solving programs } \\
\text { to investigate whether } \\
\text { children exhibited differing } \\
\text { a mounts of beha viors } \\
\text { indicative of coopera tive } \\
\text { interaction, conflict resolution, } \\
\text { effectance motiva tion, and } \\
\text { self-evaluation. }\end{array}$ & $\begin{array}{l}\text { Logo a ctivities resulted in } \\
\text { higher a chievement in } \\
\text { metacognitive processing. } \\
\text { - Research suggests that Logo } \\
\text { may foster cognitive growth } \\
\text { through opportunities for } \\
\text { resolving cognitive conflict } \\
\text { and may enhance } \\
\text { effectance motivation. }\end{array}$ \\
\hline $\begin{array}{l}\text { Nastasi, B.K., and Clements, } \\
\text { D.H. Effectance motivation, } \\
\text { perceived scholastic } \\
\text { competence, a nd higherorder } \\
\text { thinking in two cooperative } \\
\text { computer environments. } \\
\text { J oumal of Educational } \\
\text { Psychology (1994) 10:249-75. }\end{array}$ & $\begin{array}{l}48 \text { third graders } \\
\text { working in pairs }\end{array}$ & $\begin{array}{l}\text { Pretest, posttest design. } \\
\text { Partic ipants randomly assigned } \\
\text { to either Logo or c umic ulum- } \\
\text { based instruction in writing to } \\
\text { examine whether qualita tively } \\
\text { distinct computer environments } \\
\text { engender social experiences } \\
\text { that enhance motivation } \\
\text { for leaming. }\end{array}$ & $\begin{array}{l}\text { - Results suggest that } \\
\text { evaluation of success was } \\
\text { intemally determined in the } \\
\text { Logo environment, though } \\
\text { students still sought extemal } \\
\text { approval. } \\
\text { - Logo enhanced effectance } \\
\text { motivation and higher-order } \\
\text { thinking. }\end{array}$ \\
\hline $\begin{array}{l}\text { Ryan, A.W. Meta-a nalysis of } \\
\text { a chievement effects of } \\
\text { mic rocomputer a pplic ations } \\
\text { in elementa ry schools. } \\
\text { Educationa I Administration } \\
\text { Quarterly (1991) 27:161-84. }\end{array}$ & $\begin{array}{l}\text { Elementary school- } \\
\text { children (grades } \\
\text { K-6); each study } \\
\text { with a sample size } \\
\text { of at least } 40\end{array}$ & $\begin{array}{l}\text { Meta-a na lysis of compa rative } \\
\text { studies. Va ria bles a nalyzed } \\
\text { included charac teristic s of } \\
\text { students, teac hers, physic al } \\
\text { settings, a nd instructional } \\
\text { formats. }\end{array}$ & $\begin{array}{l}\text { Amount of technology- } \\
\text { related teacher tra ining } \\
\text { signific a ntly related to } \\
\text { a chievement of students. }\end{array}$ \\
\hline $\begin{array}{l}\text { Scarda ma lia, M., Bereiter, C., } \\
\text { McLean, R., et al. Computer- } \\
\text { supported intentional leaming } \\
\text { environments. J oumal of } \\
\text { Educational Computing } \\
\text { Research (1989) 5:51-68. }\end{array}$ & $\begin{array}{l}\text { Fifth and sixth } \\
\text { graders }\end{array}$ & $\begin{array}{l}\text { Students worked with a } \\
\text { collaborative computer } \\
\text { a pplic ation, Computer } \\
\text { Supported Intentional Lea ming } \\
\text { Environment (C SILE), daily for } \\
\text { almost eight months. }\end{array}$ & $\begin{array}{l}\text { Independent thinking, } \\
\text { student reflection, } \\
\text { and progressive thought } \\
\text { were maximized by CSILE. }\end{array}$ \\
\hline
\end{tabular}


Table 1 (continued)

\section{Major Studies on the Effectiveness of Computers as Leaming Tools}

\begin{tabular}{|c|c|c|c|}
\hline Study & Participants & Design and Methods & Findings \\
\hline $\begin{array}{l}\text { Schultz, LH. Pilot validation } \\
\text { study of the Sc holastic } \\
\text { Beginning Literacy System } \\
\text { (Wiggle Works) 1994-95 mid- } \\
\text { year report. Unpublished } \\
\text { paper. February } 1995 .\end{array}$ & First graders & $\begin{array}{l}\text { Three-month study in two sub- } \\
\text { urban systems (Califomia and } \\
\text { Massachussetts) and one urban } \\
\text { system (Massachussetts), in which } \\
\text { the study group used interactive } \\
\text { storybooks in addition to } \\
\text { traditional instruction to support } \\
\text { reading, writing, spea king,a nd } \\
\text { listening; control group rec eived } \\
\text { tra ditional instruction only. }\end{array}$ & $\begin{array}{l}\text { - Study group demonstrated } \\
\text { an increase in basic } \\
\text { language skills. }\end{array}$ \\
\hline $\begin{array}{l}\text { Stone, T.T. III. The a ca demic } \\
\text { impact of cla ssroom computer } \\
\text { usage upon mid dle-c lass } \\
\text { primary gra de level elementary } \\
\text { sc hool child ren. Ph.D. disser- } \\
\text { tation, 1996. Abstract in } \\
\text { Dissertation Abstracts } \\
\text { Intemational: 57/06-A. }\end{array}$ & 114 second graders & $\begin{array}{l}\text { Students the same age, same } \\
\text { socioeconomic status, and using } \\
\text { the same cumic ulum were } \\
\text { compared across two schools } \\
\text { in the same district. One } \\
\text { group used computer-assisted } \\
\text { instruction (CAl), one did not. }\end{array}$ & $\begin{array}{l}\text { - Children who used CAI } \\
\text { since kindergarten achieved } \\
\text { a significant improvement } \\
\text { in vocabula ry, reading, } \\
\text { spelling, and math problem- } \\
\text { solving a chievement. }\end{array}$ \\
\hline $\begin{array}{l}\text { Wenglinsky, H. Does it compute? } \\
\text { The relationship between } \\
\text { educational technology and } \\
\text { student achievement in } \\
\text { mathematics. Princeton, } \mathrm{NJ} \text { : } \\
\text { Educational Testing Service, } \\
\text { 1998. }\end{array}$ & $\begin{array}{l}\text { Fourth and eighth } \\
\text { graders }\end{array}$ & $\begin{array}{l}\text { National a ssessment of the } \\
\text { effects of simulation and higher } \\
\text { order thinking technologieson } \\
\text { math achievement. Data } \\
\text { analyzed controlling for } \\
\text { socioeconomic status, class size, } \\
\text { and tea cher characteristics. }\end{array}$ & $\begin{array}{l}\text { - Students who used the } \\
\text { software showed gains in } \\
\text { math level. } \\
\text { - Students whose tea chers } \\
\text { received training showed } \\
\text { gains in math scores. }\end{array}$ \\
\hline
\end{tabular}

The information provided in this table was compiled by Eva Bosch, program assistant, The David and Lucile Packard Foundation. It is included here as a starting point for further reading, but is not intended to be a comprehensive review of the literature. 